\title{
A Simple, Mild and Straight forward Route for the Synthesis of $\alpha$-Ureidopeptidomimetics Using Cbz-Protected Amino Acid Esters
}

\author{
Sagar N. Ramachandra, C. Srinivasulu, Basavaprabhu Hosamani, Santhosh L, and \\ Vommina V. Sureshbabu* ${ }^{*[a]}$
}

The synthesis of $\alpha$-ureidopeptidomimetics employing a simple, mild and straight forward route starting from benzyloxy carbonyl (Cbz-) protected amino acid esters in presence of $2-\mathrm{Cl}$ pyridine (2-chloropyridine) and $\mathrm{Tf}_{2} \mathrm{O}$ (triflic anhydride) in one- pot is described. The in situ generated isocyanate intermediates react with amino acid esters to yield the title compounds in good yields (89-96\%) and the protocol proved to be racemization free.

\section{Introduction}

The modification of peptide backbone by making chemical changes to the native peptide, or by conjugation of amino acid building blocks has been important synthetic strategy to induce stability towards peptidases with the preservation of peptide biological potency. ${ }^{[1]}$ Nowick and coworkers developed artificial $\beta$-sheets containing diurea molecular scaffolds and peptide strands. ${ }^{[2]}$ A number of natural products and pharmacologically important compounds containing uriedo linkages and ureidopeptidomimetics have also been described in the literature. ${ }^{[3]}$

For the construction of peptidomimetics, insertion of various functional groups on either terminus of amino acids is essential. More often, the desired intermediates are prepared starting from amino acids via $\mathrm{N}$ - and C-terminal modification/ substitution. Thus, amino group of an amino acid is replaced with halide, azide, hydroxy, isonitrile, isocyanato and mercapto groups which are then employed as key intermediates to assemble a designed peptidomimetic. ${ }^{[4]}$ In several cases, substitutions are made on the $\mathrm{N}$-terminus to install the functionality of choice (as in the case of $\mathrm{N}$-hydroxy, $\mathrm{N}$-amino, carbamoyl group) that enable to access the desired peptidomimetic. ${ }^{[5]}$ Urea functionality has been regarded as peptide bond surrogate and many ureidopeptidomimetics have proved to be pharmaceutically important compounds. ${ }^{[6]}$

The isocyanate derivatives of amino acid esters are useful precursors to ureidopeptidomimetics. ${ }^{[7]}$ These compounds are also useful chiral derivatizing agents and for the preparation of chiral chromatographic media. ${ }^{[8]}$ Classical method of prepara-

[a] S. N. Ramachandra, C. Srinivasulu, Dr. B. Hosamani, S. L,

Prof. V. V. Sureshbabu

\# 109, Peptide Research Laboratory, Department of Studies in Chemistry, Central College Campus, Bangalore University, Bangalore-560001 (India) E-mail: sureshbabuvommina@rediffmail.com

hariccb@gmail.com

hariccb@hotmail.com

Supporting information for this article is available on the WWW under https://doi.org/10.1002/slct.201802892 tion of isocyano ester involves use of gaseous phosgene on its

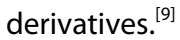

There are various methods for the synthesis of unsymmetrical urea tethered peptidomimetics. The widely employed method involves the synthesis of amino acid azide followed by its conversion to isocyanate via Curtius rearrangement followed by reaction with amino component to get corresponding urea tethered peptidomimetics. ${ }^{[10]}$ The coupling reagents EDC/ HBTU, ${ }^{[11 a]} \mathrm{T3P}^{[11 \mathrm{~b}]}$ and $\mathrm{CDI}^{[11 \mathrm{c}]}$ have been used for the preparation of acid azides, which later utilized for the synthesis of urea tethered peptidomimetics. The Lossen rearrangement of amino acid hydroxamates in presence of 1-propanephosphonic anhydride (T3P) followed by reaction with amine also gives the desired ureas. ${ }^{[11]]}$ The isocyanates derived from hydrochloride salts of amino acid esters and peptide esters have been prepared from the corresponding amino component by refluxing in toluene with purging of gaseous phosgene over a period of several hours or by the addition of a solution of phosgene in toluene either under biphasic conditions using aqueous sodium carbonate solution or by using excess of pyridine. ${ }^{[12-14]}$ Triphosgene [bis(trichloromethyl)carbonate] is preferred as an alternative over phosgene, though reported to result in contaminants. ${ }^{[15]}$ Thus, the application of the above approaches, in principle, needs the conversion of $\alpha$-amino group of amino acid esters or peptide esters to isocyanates which can be used directly or via carbamates to prepare ureidopeptides. These methods, in general, involve multiple steps and further require preparation of reagent, long reaction time, and use of large excess of reagents. One of the three commonly employed protected groups in peptide synthesis is $\mathrm{Cbz}$-protecting group. The Cbz-amino acids are crystalline, shelf stable solids and are commercially available and cheap. The $\mathrm{Cbz}$ group is stable under basic and acidic conditions, and can be removed by catalytic hydrogenation or by strong acid. However, the direct synthesis of $\alpha$-ureidopeptides starting from Cbz-protected amino acid esters has not yet arrived in the literature. Therefore, the development of such a route would be advantageous for the synthetic community. To the best of 
our knowledge, a facile, divergent one-pot route using in situgenerated isocyanates for the synthesis of $\alpha$-ureidopeptides from Cbz-protected amino acid esters is the first report of its kind. Trifluoromethanesulfonic (triflic) anhydride-pyridine conjunction upon activation of amides has found to show conversion to various functional groups on treatment with suitable nucleophiles. ${ }^{[16]}$ Inspired by the recent reports on the reaction of Boc and $\mathrm{Cbz}$-protected amines for the synthesis of unsymmetrical ureas, ${ }^{[17,18]}$ herein, we report the one-pot synthesis of $\alpha$-ureidopeptides from Cbz-protected amino acid esters devoid of any coupling agents.

\section{Results and Discussion}

We investigated the preparation of $\alpha$-ureidopeptides starting from Cbz-protected amino acid esters in presence of suitable base and triflic anhydride $\left(\mathrm{Tf}_{2} \mathrm{O}\right)$. In a typical experiment, to a solution of Cbz-Val-OMe (1a) (1.0 equiv) in dry $\mathrm{CH}_{2} \mathrm{Cl}_{2}$, 2chloropyridine (2.5 equiv.) was added followed by slow addition of $\mathrm{Tf}_{2} \mathrm{O}$ (1.5 equiv) and stirred at room temperature. The formation of isocyanate was found to be completed in 15$20 \mathrm{~min}$ as monitored by thin layer chromatography (TLC). To the in situ formed isocyanate, was added a solution of Phg-OEt (2a) (2.5 equiv.) to afford the title compound in $79 \%$ yield in $6 \mathrm{~h}$. In order to enhance the yield, parallely, various bases and their equivalence along with $\mathrm{Tf}_{2} \mathrm{O}$ and amino acid esters has also been optimized to obtain suitable reaction conditions. First, commonly employed bases $\mathrm{N}$-methylmorpholine (NMM) and $\mathrm{N}, \mathrm{N}$-diisopropylethylamine (DIEA) were employed. However these studies did not yield desired product in either case (entries 2 and 3). When pyridine was employed as a base, the product was obtained, albeit in $24 \%$ yield (entry 4). 2,6-Lutidine also failed to improve the yield even when equivalence was varied (entry 5 and 6). Significant improvement in yield (45\%) was noticed when 2-fluoropyridine was used as base (entry 7). Alongside, various solvents viz. $\mathrm{CH}_{3} \mathrm{CN}$, EtOAc, $\mathrm{MeOH}$, THF and $\mathrm{CH}_{2} \mathrm{Cl}_{2}$ were screened. Howbeit, no significant improvement in yield was noticed among the solvents except $\mathrm{CH}_{2} \mathrm{Cl}_{2}$ and so was found efficient for the formation of desired product (3a). Finally 2-chloropyridine was employed with varying equivalences (entries 8-11), however the best result was obtained in presence of 3.0 equiv. of 2-chloropyridine with $96 \%$ yield. Also, the use of 1.5 equiv. of $\mathrm{Tf}_{2} \mathrm{O}$ in dry $\mathrm{CH}_{2} \mathrm{Cl}_{2}$ and 3.0 equiv. of amino acid ester found to yield the desired product in good yield in 6-10 $\mathrm{h}$.

With the optimized reaction conditions in hand, the generality of this one-pot procedure for the synthesis of $\alpha$ ureidopeptides was explored. The reaction turned out to be tolerant of various $\mathrm{Cbz}$-protected amino acid esters and amino esters. The advantage of the current methodology is the mild reaction conditions, which enable the isocyanate to react with amine to form desired products. The title compounds were obtained in high yields (89-96\%).

Racemization studies were performed to check the optical homogeneity of the compounds resulting from this protocol. The RP-HPLC profiles were analyzed for the epimeric products $\mathbf{3} \mathrm{d}$ and $\mathbf{3} \mathrm{d}^{*}$. Compounds $\mathbf{3} \mathrm{d}$ and $\mathbf{3} \mathrm{d}^{*}$ showed retention times

\begin{tabular}{|c|c|c|c|c|}
\hline \multirow[b]{2}{*}{ Entry } & \multirow[b]{2}{*}{ Base (equiv.) } & \multicolumn{2}{|c|}{$\begin{array}{l}\text { 1. Base (equiv.), } \mathrm{Tf}_{2} \mathrm{O} \text { (equiv.) } \\
\mathrm{CH}_{2} \mathrm{Cl}_{2}, 30 \mathrm{~min} \text {, r.t. }\end{array}$} & \multirow[b]{2}{*}{$\begin{array}{l}\text { Yield } \\
(\%)^{\mathrm{b}}\end{array}$} \\
\hline & & $\begin{array}{c}\mathrm{Tf}_{2} \mathrm{O} \\
\text { (equiv.) }\end{array}$ & $\begin{array}{c}\text { Amino acid ester } \\
\text { (equiv.) }\end{array}$ & \\
\hline 1 & None & 1.5 & 2.5 & 0 \\
\hline 2 & NMM (3.0) & 2.0 & 3.0 & 0 \\
\hline 3 & DIEA (2.5) & 1.5 & 3.0 & nd \\
\hline 4 & Pyridine (2.5) & 2.0 & 3.0 & 24 \\
\hline 5 & $\begin{array}{l}\text { 2,6-Lutidine } \\
\text { (2.5) }\end{array}$ & 1.5 & 2.5 & 29 \\
\hline 6 & $\begin{array}{c}\text { 2,6-Lutidine } \\
\text { (3.0) }\end{array}$ & 2.0 & 3.0 & 31 \\
\hline 7 & $\begin{array}{c}\text { 2-F-Pyridine } \\
(2.5)\end{array}$ & 1.5 & 3.0 & 45 \\
\hline 8 & $\begin{array}{c}\text { 2-Cl-Pyridine } \\
\text { (2.5) }\end{array}$ & 1.5 & 2.5 & 79 \\
\hline 9 & $\begin{array}{c}\text { 2-Cl-Pyridine } \\
\text { (3.0) }\end{array}$ & 1.5 & 3.0 & 96 \\
\hline 10 & $\begin{array}{c}\text { 2-Cl-Pyridine } \\
\text { (3.0) }\end{array}$ & 2.0 & 3.0 & 86 \\
\hline $11^{\mathrm{a}}$ & $\begin{array}{c}\text { 2-Cl-Pyridine } \\
\text { (3.0) }\end{array}$ & 2.5 & 3.0 & 83 \\
\hline
\end{tabular}

$\mathrm{NMM}=\mathrm{N}$-Methylmorpholine. $\mathrm{DIEA}=\mathrm{N}, \mathrm{N}-$ Diisopropylethylamine. ${ }^{\mathrm{a}}$ Reaction mixture stirred at $45{ }^{\circ} \mathrm{C}$ for $10 \mathrm{~h}$. ${ }^{\text {b }}$ Yield obtained after column chromatography. $\mathrm{nd}=$ not determined.
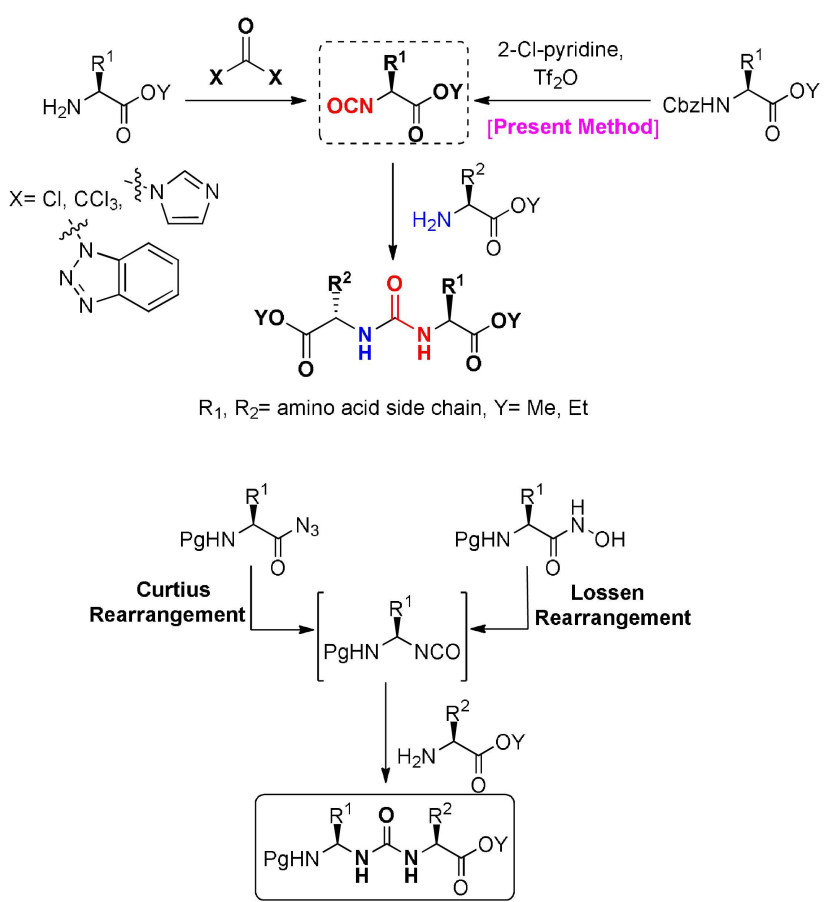

Scheme 1. Synthesis of urea tethered peptidomimetics through various routes reported in literature. 


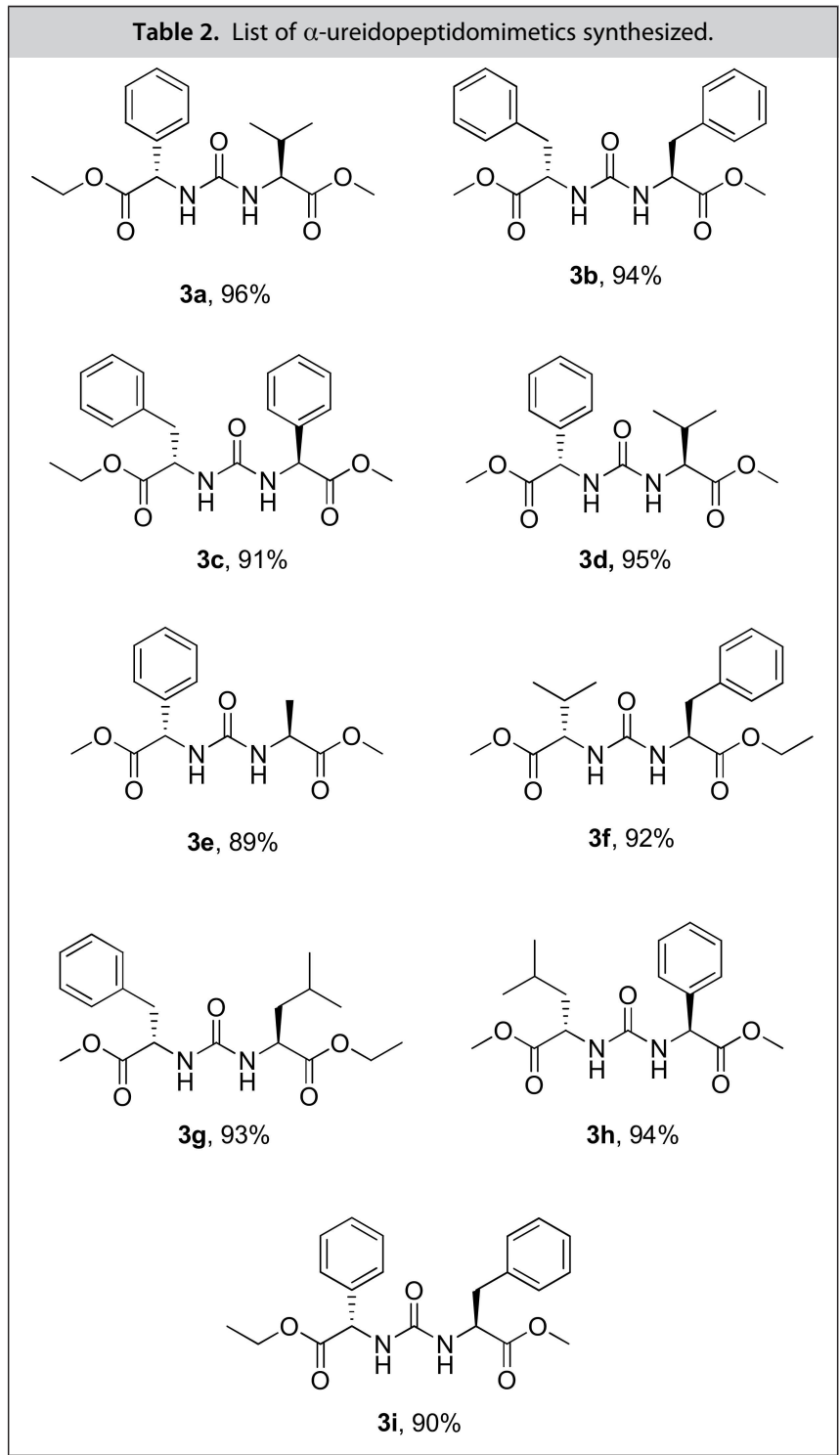

$$
\text { 2. }
$$

$\mathrm{R}^{1}, \mathrm{R}^{2}=$ amino acid side chain

$$
\mathrm{Y}=\mathrm{Me}, \mathrm{Et}
$$

Scheme 2. Synthesis of $\alpha$-ureidopeptides from Cbz-protected amino acid esters.

$\left(R_{t}\right) 6.123 \mathrm{~min}$ and $4.376 \mathrm{~min}$ respectively. In supplement, consciously prepared equimolar mixture of $3 \mathrm{~d}$ and $3 \mathrm{~d}^{*}$ showed distinct retention times of 6.262 and $4.433 \mathrm{~min}$ respectively. These evidences from the analyses ensured that the reaction does not suffer from racemization and hence the protocol was racemization-free.<smiles>COC(=O)C(NC(=O)N[C@@H](C(=O)OC)C(C)C)c1ccccc1</smiles>

3d<smiles>COC(=O)[C@@H](NC(=O)N[C@@H](C(=O)OC)c1ccccc1)C(C)C</smiles>

$3 \mathbf{d}^{*}$
Figure 1. Epimers synthesized for the racemizatuion studies.

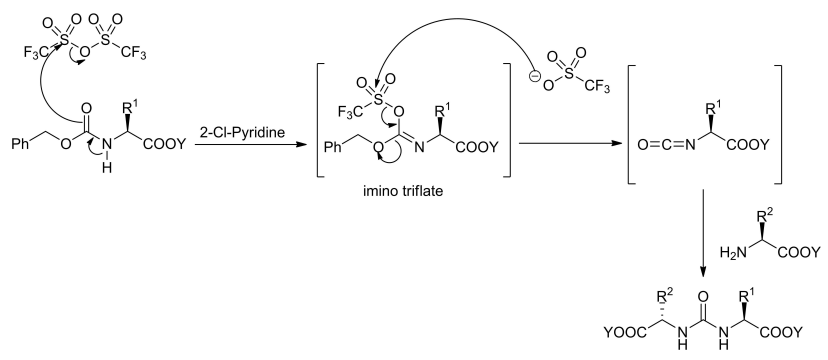

Figure 2. Plausible mechanism for the formation of $\alpha$-ureidopeptides.

In the possible mechanism, initially 2-Cl-pyridine as a base abstracts proton from the amide $\mathrm{N}-\mathrm{H}$ and thereby facilitating the $\pi$-electrons of the carbonyl group to add to one of the sulfur atoms of triflic anhydride with the release of one molecule of trifluorosulfonate. Thus formed imino triflate intermediate then undergoes rearrangement with the assistance of liberated sulfonates resulting in the formation of corresponding amino acid ester isocyanate. Then the addition of amino acid ester to this in situ generated isocyanate led to the formation of desired $\alpha$-ureidopeptides.

\section{Conclusions}

In conclusion, we have developed a simple and straight forward route for the synthesis of $\alpha$-ureidopeptides (without any coupling agents) starting from $\mathrm{Cbz}$-protected amino acid ester and amino ester under mild reaction conditions, in presence of $2-\mathrm{Cl}$ pyridine and $\mathrm{Tf}_{2} \mathrm{O}$. The protocol resulted in $\alpha-$ ureidopeptides in good yields (89-96\%). Also the protocol is devoid of racemization.

\section{Supporting Information Summary}

Procedure for synthesis of $\alpha$-ureidopeptidomimetics, HRMS, ${ }^{1} \mathrm{H}$, ${ }^{13} \mathrm{CNMR}$ spectra and characterization data of compounds (3a-i), and RP-HPLC data are appended in the supporting information.

\section{Acknowledgements}

We thank Science and Engineering Research Board (SERB) (Grant No.EMR/2016/002432), Govt. of India for the financial support. 


\section{Conflict of Interest}

The authors declare no conflict of interest.

Keywords: 2 -Chloropyridine $\cdot$ isocyanate $\cdot$ triflic anhydride $\cdot \alpha$ ureidopeptidomimetics

[1] a) V. Semetey, C. Hemmerlin, C. Didierjean, A. P. Schaffner, A. G. Giner, A. Aubry, J. P. Briand, M. Marraud, G. Guichard, Org. Lett. 2001, 3, 38433846; b) A. C. Myers, J. A. Kowalski, M. A. Lipton, Bioorg. Med. Chem. Lett. 2004, 14, 5219-5222; c) L. Fischer, C. Didierjean, F. Jolibois, V. Semetey J. Manuel Lozano, J. P. Briand, M, Marraud, R. Poteau, G. Guichard, Org. Biomol. Chem. 2008, 6, 2596-2610.

[2] J. S. Nowick, Acc. Chem. Res. 1999, 32, 287.

[3] a) I. Gallou, Org. Prep. Proced. Int. 2007, 4, 355-383; b) F. Bigi, R. Maggi, G. Sartori, Green Chem. 2000, 2, 140-148; c) T. P. Vishnyakova, I. A Golubeva, E. V. Glebova, Russ. Chem. Rev. (Engl. Ed.) 1985, 54, 249-261; d) K. Matsuda, Med. Res. Rev. 1994, 14, 271-305; e) T. Kishida, N. Fujita, K. Sada, S. Shinkai, Langmuir. 2005, 21, 9432-9439; f) J. J. E. Moreau, L. Vellutini, M. W. C. Man, C. Bied, Chem. -Eur. J. 2003, 9, 1594-1599.

[4] J. Lutz, H. -J. Musiol, L. Moroder in Houben-Weyl: Synthesis of Peptides \& Peptidomimetics, Vol. E22a (Eds.: M. Goodman, A. Felix, L. Moroder, C. Toniolo) Georg Thieme, Verlag: Stuttgart, New York, 2004, pp. 427.

[5] a) Houben-Weyl: Synthesis of Peptides \& Peptidomimetics, Vol. E22c (Eds.: M. Goodman, A. Felix, L. Moroder, C. Toniolo) Georg Thieme, Verlag: Stuttgart, New York, 2003; b) Peptides: Chemistry and Biology, (Eds.: N Sewald, H. D. Jakubke, Wiley-VCH, Weinheim, 2002; c) M. Chorev, Peptide Science. 2005, 80, 67-84.

[6] a) V. Semetey, D. Rognan, C. Hemmerlin, R. Graff, J. -P. Briand, M. Chem. Int. Ed. 2002, 41, 1895-1898; c) C. Y. Cho, E. J. Moran, S. R. Marraud, G. Guichard, Angew. Chem., Int. Ed. 2002, 41, 1893-1895; b) V. Semetey, C. Didierjean, J. -P. Briand, A. Aubry, G. Guichard, Angew. Cherry, J.C. Stephans, S. P. Fodor, C. L. Adams, A. Sundaram, J.W. Jacobs, P. G. Schultz, Science 1993, 261, 1303-1305; d) X. Wang, I. Huq, T. M. Rana, J. Am. Chem. Soc. 1997, 119, 6444-6445; e) N. Tamilarasu, I. Huq, T. M. Rana, Bioorg. Med. Chem. Lett. 2001, 11, 505-507; f) N. Tamilarasu, I. Huq, T. M. Rana, J. Am.Chem. Soc. 1999, 121, 1597-1598; g) K. A. Jones, B. M. Peterlin, Annu. Rev. Biochem. 1994, 63, 717-743; h) J. A. Patch, A. E. Barron, Curr. Opin. Chem.Biol. 2002, 6, 872-877; i) W. P. Esler, W. T. Kimberly, B. L. Ostaszewski, W. Ye, T. S. Diehl, D. J. Selkoe, M. S. Wolfe, Proc. Natl. Acad. Sci. U. S. A. 2002, 99, 2720-2725; j) P. Bakshi, M. S. Wolfe, J. Med. Chem. 2004, 47, 6485-6489; k) W. P. Esler, C. Das, M. S. Wolfe, Bioorg. Med. Chem. Lett. 2004, 14, 1935-1938; I) D. P. Getman, G. A. de Crescenzo, R. M. Heintz, K. L. Reed, J. J. Talley, M. L. Bryant, M. Clare, K. A Houseman, J. J. Marr, R. A. Mueller, J. Med. Chem. 1993, 36, 288-291; m) K. E. Kick, J. A. Ellman, J. Med. Chem. 1995, 38, 1427-1430; n) P. Y. Lam, P. K. Jadhav, C. J. Eyermann, C. N. Hodge, Y. Ru, L. T. Bacheler, J. L. Meek, M. J. Otto, M. M. Rayner, Y. N. Wong, C.-H. Chang, P. C. Weber, D. A. Jackson, T. R. Sharpe, S. Erickson-Viitanen, Science 1994, 263, 380384; o) M. A. Navia, M. D. P. Fitzgerald, B. M. Mckeever, C.-T. Leu, J. C. Heimbach, W. K. Herber, I. S. Sigal, P. L. Darke, J.P. Spronger, Nature
(London) 1989, 337, 615-620; p) A. Wlodawer, M. Miller, M. Jaskolski, B. K. Sathyanarayana, E. Baldwin, I. T. Weber, L. M. Selk, L. Clawson, J. Schneider, S. B. H. Kent, Science 1989, 245, 616-621; q) A. Brik, C.-H. Wong, Org. Biomol. Chem. 2003, 1, 5-14; r) S. Stefanelli, L. Cavaletti, E. Sarubbi, E. Ragg, L. Colombo, E. J. Selva, Antibiot. 1995, 48, 332-334.

[7] a) K. Burgess, H. Shin, S. Linthicum, Angew.Chem.,Int.Ed. 1995, 34, 907909; b) K. Burgess, J. Ibarzo, D. S. Linthicum, D. H. Russell, H. Shin, A Shitangkoon, R. Totani, A. J. Zhang, J. Am. Chem. Soc. 1997, 119, 15561564; c) M. E. Wilson, J. S. Nowick, Tetrahedron Lett. 1997, 39, 6613-6616; d) P. Claudon, A. Violette, K. Lamour, M. Decossas, S. Fournel, B. Heurtault, J. Godet, Y. Mely, B. Jamart-Gregoire, M. -C. Averlant-Petit, J. -P. Briand, G. Duportail, H. Monteil, G. Guichard, Angew. Chem., Int. Ed. 2010, 49, 333-336; e) L. Fischer, P. Claudon, N. Pendem, E. Miclet, C. Didierjean, E. Ennifar, G. Guichard, Angew. Chem., Int. Ed. 2010, 49, 10671070

[8] a) W. H. Pirkle, M.S. Hoekstra, J. Org. Chem. 1974, 39, 3904-3906; b) W. H. Pirkle, K. A. Simmons, C. W. Boeder, J. Org. Chem. 1979, 44, 4891-4896; c) W. H. Pirkle, M. H. Hyun, J. Chromatogr. 1986, 322, $295-$ 307; d) W. D. Armstrong, C. -D. Chang, S. H. Lee, J. Chromatogr. 1991, 539, 83-90.

[9] a) H. Babad, A. G. Zeiler, Chem. Rev. 1973, 73, 75-91; b) M. B. Smith, J. March, March's Advanced Organic Chemistry: Reactions, Mechanisms, and Structure, 5thed, Wiley: New York, 2001, p1191; c) H. -J. Knoelker, T. Braxmeier, G. Schlechtingen, Angew. Chem., Int. Ed. Engl. 1995, 34, 24972500.

[10] a) S. P. Basanagoud, G. R. Vasanthakumar, V. V. Sureshbabu, J. Org Chem. 2003, 68, 7274-7280; b) V. V. Sureshbabu, S. P. Basanagoud, R Venkataramanarao, J. Org. Chem. 2006, 71, 7697-7705.

[11] a) V. V. Sureshbabu, H. S. Lalithamba, N. Narendra, H. P. Hemantha, Org Biomol. Chem. 2010, 8, 835-840; b) Basavaprabhu, N. Narendra, R. S Lamani, V. V. Sureshbabu, Tetrahedron Lett. 2010, 51, 3002-3005; c) B. Vasantha, T. M. Vishwanatha, V. V. Sureshbabu, Prot. Pept. Lett. 2011, 18, 1093-1098; d) B. Vasantha, H. P. Hemantha, V. V. Sureshbabu, Synthesis. 2010, 17, 2990-2996.

[12] a) S. Goldschmidt, M. Z. Wick, Naturforsch.B. 1950, 5b, 170; b) S. Goldschmidt, M. Wick, Liebigs Ann. Chem. 1952, 575, 217-231.

[13] J. S. Nowick, N. A. Powel, T. M. Nguyen, G. Noronha, J. Org. Chem. 1992, $57,7364-7366$

[14] J. S. Nowick, D. L. Holmes, G. Noronha, E. M. Smith, T. M. Nguyen, J. Org. Chem. 1996, 61, 3929-3934.

[15] a) P. Majer, R. S. Randad, J. Org. Chem. 1994, 59, 1937-1938; b) J. S. Norwich, N. A. Powell, T. M. Ngugen, G. Noronha, J. Org. Chem. 1992, 57 7364-7366.

[16] a) I. L. Baraznenok, V. G. Nenajdenko, E. S. Balenkova, Tetrahedron. 2000 56, 3077-3119. b) A. B. Charette, M. Grenon, Can. J. Chem. 2001, 79, 1694-1703.

[17] C. Spyropoulos, C. G. Kokotos, J. Org. Chem. 2014, 79, 4477-4483.

[18] H. K. Kim, A. Lee, Org. Biomol. Chem. 2016, 14, 7345-7353.

Submitted: September 14, 2018

Accepted: November 6, 2018 